\title{
The Development of Pragmatics Learning Tools to Improve Critical Thinking Skills
}

\author{
Ni Made Rai Wisudariani ${ }^{1}$, Sang Ayu Putu Sriasih ${ }^{2}$ \\ Universitas Pendidikan Ganesha \\ Singaraja, Indonesia \\ rai.wisudariani85@gmail.com ${ }^{1}$, sap.sriasih.undiksha.ac.id ${ }^{2}$
}

\begin{abstract}
The research development in the first stage was aimed at arranging prototype of Pragmatics learning tools oriented problem-based learning model which could improve understading concept and students' ability to think logically and critically. The subject of this study were both Ganesha University of Education, Undiksha lecturers and the students of Indonesian Language and Literature Study Program in the $4^{\text {th }}$ semester. The research method used was descriptive qualitative method that compraised the fourth semester students and lecturer in Indonesian Language and Literature Study Program at Ganesha University of Education as the subject of the study. The data were collected through questionnaire, interview and document study. The result of this research showed that learning tool which was required by lecturers and students in Pragmatics learning course including syllabus, lesson plan, textbooks, media and assessment oriented on contextual and actual political social problem became the polemics in social life.
\end{abstract}

Keywords-learning tool; critical thinking

\section{INTRODUCTION}

Language is defined as the means of communication used to exchange information and to share ideas, but it is sometimes that the information or ideas spoken by the speakers have the hidden meaning itself. The listener must be able to understand intention and meaning of the information spoken by the speakers. Understanding the meaning of the speech is not only enough to comprehend the meaning of each of element in the form of information spoken by speakers. Other elements also influence the meaning of information spoken which is related to the context of the language.

In understanding the speech, the listener may not only focus on the context in the form of language text, but there are other factors that should be concerned about. Those are both physical and social contex. It is also the prior knowledge which are owned by both speakers and listeners [1-3]. In case, the listeners do not understand what might be already spoken by the speakers, but also to understand the contexts of speech being spoken. Those aspects as explained above is worth considering its truth as the major factors which effect the use of language in daily life might often cause misunderstanding, so the meaning of the utterance spoken by the speaker is not well-understood.

In line with above situation, the pragmatic learning course is one of the functional language courses that has a strategic role in equipping students with an understanding of the concept of meaning of speech, improving students' critical thinking skills in understanding the meaning of speech, improving students' skills in communicating effectively, and solving problems - issues which is related to the scope of meaning of speech. Students as future teachers are expected to be sensitive about their context when they speak. The students ways of communicating will greatly determine the quality of the students' personality.

Students are considered as a human being who are already mature, they are not only required to understand the concept of the material and communicate it, but the students must also be able to communicate reasonably. Students are required to have the ability to think further, namely on the level of analysis, synthesis and evaluation. The ability to think is a high level of thinking skills called critical thinking. Ennis argued, critical thinking is reasoned and reflective thinking by emphasizing decision-making on what to believe or do [4].

The definition of critical thinking refers to one's ability to make and conduct evaluation on the evidence based conclusion [4] [5]. It is also very important in today's life since we have faced various political speech, news, conversations, newspapers, tabloids, advertisements, and the internet that are not absolutely true. Students should be given the skills to identify the intentions or meaning of this non-neutral speech.

The critical thinking literacy does not only teach the students to master basic skills such as understanding, predicting and summarizing, but training students to be critical in every context of the speech they receive. This critical thinking ability is absolutely necessary for students and intellectuals, just because every opportunity they will decide on various issues, it is either related to their field of science or social problems.

It has the purpose that the lecturer should be able to develop a pragmatic learning tool oriented problem-based learning which is appropriately applied with the needs of lecturers and students [6]. By having the right learning tool, the learning direction will become clear and the learning objectives can be well-achieved [7-11]. Theoretically, the development of this learning tool becomes one of the guidelines in developing aspects of language especially on Pragmatics study. In addition, the results of this development also provides an overview of the phenomenon and reality of language that is no longer formed in structuralist educational texts.

\section{METHODS}

The development of this learning device used research and development model of 4D model (Define, Design, Develop, and Diseminate) proposed by Thiagarajan et.al [12]. In the 
first year, the research conducted define and design stage. Through this research, it was investigated to know the needs of students and lecturers, the problems of using the language that could be used as material tools, and materials and strategies which were appropriate in Pragmatics learning course.

Subjects who became respondents at this stage were 40 students of the fourth semester of the Indonesian Language and Literature Education Study Program which programmed the Pragmatics learning course and lecturers at the Indonesian Language and Literature Education Study Program, Undiksha.

There were several steps conducted in this study. The first step, it observed the needs of students in the Pragmatics learning course and giving questionnaires to the respondents who have been set. The second step, it tabulated and analyzed descriptively quantitative students' answers. The third step, it identified the respondents who deserved to be informants. The fourth step, it conducted interview which was established informants and collected the data from documents. The fifth step, it transcribed the recording of the interview and analyzed it by using inductive transcription data and the last one, it reviewed syllabus and lesson plan of Pragmatics. The results of this study were a list political issues which were needed by the students in pragmatics learning course.

The results of this study were a list of conceptual analysis, indicators of competency achievement, study of the tasks students would be done, and the study of students' critical thinking skills, the ability of students to communicate, and problem-based learning in the literature study and findings which was relevant to the development Pragmatic devices. The learning contexts on field study was also used as materials for designing prototype learning devices.

The data that had been collected were processed descriptively and qualitatively. The result showed that the conclusion of the needs of students and lecturers in Pragmatics course. The data from the results of given questionnaires were analyzed quantitatively-qualitatively. Meanwhile, data from observation, interview and document recording were analyzed qualitatively. The stages of analysis started from identifying the results of needs analysis, documentation of appropriate learning materials, prototype preparation. Afterwards, the analysis of prototype learning devices in the panel group discussion was conducted to obtain a prototype fit conceptually. Discussion results were used as one of the basic development of prototype learning tool Pragmatic oriented problem-based learning.

\section{FINDINGS}

Based on the results of the identification of the lecturer and students needs in Pragmatics course, it can be seen that the needs of students and lecturers for the Pragmatics learning course were the availability of learning tools Pragmatic oriented problem-based learning model designed with systematic steps and easy to be understood by the students.

The learning tools consist of syllabus, lesson plan, textbook, learning media, and assessment. Syllabus and lesson plan were used as a tool of plans and arrangements regarding the content and lesson materials as well as the means and technique used to teach. This learning planning was used as a guidance in the implementation of teaching and learning activities. It consisted of the answer to these questions: (1) what will be taught; (2) what is the goal to be achieved; (3) how to carry out the learning activities; (4) how is time allocation in learning activity; and (5) how to know that the learning objectives have been achieved.

Another required tool is a textbook, in which it is a systematic set of materials that lecturers needed as a means of teaching and as well as students to learn. In Undang-undang Pendidikan Tinggi nomor 12 Tahun 2012, Pasal 12, Ayat 3 (the Law of Higher Education Number 12 of 2012, Article 12, Ayat 3) mentioned one of the obligations of lecturers is to write textbook as one of the learning resources for students. In addition, one form of appropriate teaching materials was developed in the learning as the presentation of teaching materials in the form of textbooks.

The development of learning materials in the form of textbooks can support individual and independent learning, facilitate student learning, and met the qualifications as a good learning material and that required the principles of learning development. By using textbooks, the students can learn more effectively. Lectures activity by using textbooks enabled students to learn actively, quickly, and with maximum results. So far, many lectures were designed to be classical, that was, assumed the ability of each students were just the same. By using textbooks, students during lecturing/learning process will have readiness and enable the acceleration of learning.

Students aware with high absorptive ability were given the opportunity to complete their learning tasks faster than the time specified. Students who had difficulty in learning would receive sufficient attention through the process of guidance and remedial teaching. Another development of teaching materials in the form of textbooks, which was also a requirement was the preparation of quality assessments tailored to the learning process. Assessment instruments were used as a basis to know the level of achievement of learning objectives. Assessment can be used as a reference by lecturers and students in measuring the success of learning.

Learning media in the form of powerpoint was also required by the students to the lecturer. Through the media used by the lecturer, the students became focus and understand the material described by the lecturer. Those five tools needed to be developed in such a way in order to create learning that was relevant to the needs of students and being able to provide meaningful results for students. That way, learning would really give satisfaction results for students' progress.

There were various materials and topic issues tested in this lesson. Based on the results of questionnaires, materials and topics of problems that can improve the understanding of the concept and the ability of critical thinking of students, namely (1) historical material of pragmatics development with the topic of the issues raised "Why Pragmatics can not develop from 1938 when it was introduced by Morris at that time, 90\% student respond positively to this material, (2) the material of pragmatics relation with other linguistics on the topic of the 
question raised "Why Pragmatics can explain the broader utterances of Semantics" and explain by example that one day Sociolinguistics can support the study of Pragmatics, 88\% student respond positively to this material, (3) matter Determinants of intent: text, context, and the context of the topic raised "DP", 90\% student respond positively to this material, (4) the material nature of deixis in the study of Pragmatics wit the topic of the issue raised" pay it today and it is free for tomorrow", $87 \%$ student respond positively to this material, (5) the material nature of speech acts with the topic of the issues raised "the speech acts of Lecturer in learning activities" 92\% student respond positively to this material, (6) the material presupposition, implicature, and inference in the study of the pragmatic to the topic of the issues raised "presupposition, implicature, and inference speech of Cak Lontong Show" 92\% student respond positively to this material, (7) the material principles of cooperation in the study of Pragmatics to the topic of the issues raised "speech of students in the interaction of presentation and discussion in the classroom" $90 \%$ student respond positively to this material and (8) materials politeness principle in pragmatics study to the topic of the issues raised by the topic of "speech of lecturers and students in teaching and learning activities" 90\% student respond positively to this material.

The results of questionnaire and interview showed that there were various materials and political issues needed in this lesson. The issues needed were; (1) matter determinants of intent: text, co-text, and the context of the topic raised "Negara Kesatuan Republik Indonesia harga mati" 93\% student respond positively to this material, (2) the material presupposition, implicature, and inference in the study of the pragmatic to the topic of the issues raised "presupposition, implicature, and inference speech of Ahok in "Kepulauan Seribu", 98\% student respond positively to this material (3) the topic analysis of speech acts of Majelis Ulama Indonesia Fatwa, 90\% student respond positively to this material (4) implicatures participants of "Indonesian Lawyers Club" in the topic of "bring Jakarta back", 95\% student respond positively to this material (5) implicatures language of politicians in the election of governor in Jakarta in 2017, $90 \%$ student respond positively to this material (6) implicatures meme politics during the governor election campaign period in Jakarta, 93\% student respond positively to this material (7) implementation and violations of the principle of cooperation and civility in debates regarding governor election in Jakarta, 92\% student respond positively to this material.

\section{DISCUSSIONS}

The results of this study indicated that learning tools which were required by lecturers and students consisted of syllabus, lesson plan, textbooks, learning media, and assessment. The results of this study indicated that learning tools that was required by lecturers and students consisted of syllabus, lesson plan, textbooks, learning media, and assessment. Syllabus and lesson plan in this study was developed with reference to Presidential Regulation No. 8 of 2012 on the Indonesian National Qualification Framework which became the reference of Ganesha University of Education. The achievement of Kerangka Kualifikasi Nasional Indonesiabased learning was the ability gained through the internalization of knowledge, attitudes, skills, competencies, and accumulated work experience.

The components syllabus consisted of the components of the course identity, the content component that included course achievements, course descriptions, review materials, references, and the identity of the course learner. Components in lesson plan consisted of the components of the identity of the courses consisting of the names of courses/majors, names and codes of courses, semesters, sks, js, and pengampu course. Components of lesson plan content consisted of graduate learning achievement, final competency, study material, method, time, learning experience, criterion of indicator of rating weight, and reference. On this basis, it was identified the gap of critical thinking attitudes that can be raised in learning planning.

A syllabus component that can be loaded with a critical thinking attitude was on the learning achievement component and course description. Achievement of learning was expressed in the three elements of attitude. There were knowledge, and skills are divided into general and special skills. Behavioral elements was attitudes possessed by students in learning. The element of knowledge concerned on the mastery of student knowledge. Elements of skills characterized the ability of graduates of study programs to suit a particular field of knowledge/skills, while general skills characterized the ability of graduates according to the level and type of educational program.

The ability of thinkng critically can be explored into attitudes. In addition to the learning achievements, this ability was also explicited in the course description. Course description provided an overview of the course. This description was an explanation of the topics of socio-political issues to be studied in pragmatics courses.

In lesson plan, critical thinking skills was explicited in learning achievements, final competencies, learning experiences, attitude criteria, and assessment. In the final competency component was designed by several capabilities achievement that would be achieved in each meeting. In every meeting it was expected that students' critical thinking ability would increase, instead. In the component of student learning experience, it was also described the attitude that was expected to appear in the learning. Learning experience was manifested in the description of the learning stages to be done By students for one semester. The next component was the attitude criterion. Attitudinal criteria became a measure of attitudes that arise in learning process. In the assessment component, there were tasks that was explicitly demanded the emergence of students' critical thinking skills in reviewing the speech.

Syllabus and lesson plan were used as guidance in learning [13]. The task of educators was to plan the emergence of students' critical thinking skills that would be formed in learning. The designed syllabus and lesson plan were essentially a short-term plan to estimate the improvement of 
critical thinking skills that would be implanted to learners in learning.

In preparing the syllabus and lesson plan, it should be clear both competence and attitudes that would be owned by learners, what to do, what to learn, how to learn, and how learners know that learners had the ability to think critically. The main thing to do was to identify a political case that can be raised in Pragmatics learning, integrating material and political case in learning planning, and preparing syllabus and lesson plan which was loaded with politician's speech causing political case.

For educators, integrating issues that required critical thinking in the syllabus and lesson plan provided clear guidance on instructional materials, the setting of methods, and the implementation of learning. Educators became more prepared in learning. Well-prepared learning with good planning was more effective in shaping the character of learners as planned. For students, through syllabus and lesson plan can be known the purpose of learning, the level of mastery, and the criteria of goal achievement [14-18].

Pragmatic material had a central role in intellectual, social, and emotional development of students and it was a supporter of success in understanding the purpose of communication. Pragmatic learning was expected to help students to recognize themselves, their culture, and other people's cultures, express ideas and feelings, participate in societies that use the language, and discover and use their own analytical abilities. The scope of the Pragmatic Constitution covered the component of spoken language skills in interactional communication. Based on the characteristics of the Pragmatic Court, the learning materials can be juxtaposed with political speeches that require critical review.

The loading of critical studies in textbooks was done through the identification of instructional materials and the assessment of critical speech in accordance with the material being taught. Identification was done so that there was a suitability between the critical issues and learning materials developed. To integrate critical attitudes into textbooks was that the material in textbooks needed to be prepared by adding critical matter materials into the components of the subject matter discussed in it [19], [20]. If the educator was merely following or implementing the lesson based on a textbook that does not integrate critical speech material, the learning activities would not reflect the inculcation of critical thinking skills in the student.

Designed in the planning of learning that has a critical attitude, the textbook needs to be adapted [21]. Adaptation that can be done was to include critical issues that were relevant to the substance of the material. Therefore, educators need not to change the existing subject matter. Educators can use existing subjects to develop students' critical thinking skills.

The textbooks oriented problem-based learning was a textbook that allows educators were able to present teaching materials in such a way that students are able to understand, determine attitudes, and behave based on the teaching materials. In this case, the textbook served as a tool for establishing competence, shaping attitudes, assessment tools, and the foundation for higher characters in subsequent material.

The result of the questionnaire regarding the use of instructional media as a discussion material resulted in other findings that were also urgent to be discussed. The result of students' response was generally related to media usage indicated that the discussion material presented through audiovisual media was able to combine visual and audio elements, so that the content of the material / message was more easily absorbed by the students [22].

The content of the material or message was more easily absorbed because it activated the two senses of the sense of hearing and the sense of sight. Both of these senses will form the emotions and mindset of students to the problems presented. Learning media can prepare students to understand the speech and respond to contradictory life. The results of this study at once diminished the notion that the media was only suitable for children. Learning media is very effective to use in recovery.

Assessment tools were also required by students. The assessment oriented problem based-learning emphasized the achievement of basic competencies by using various assessment techniques in an effort to monitor and determine improvement programs. This lesson did not only lead to learning on the theory or skills of students, but also included the attitude of planting a critical attitude.

The degree of success of understanding and internalization of matter and attitudes must be measurable through appropriate assessment, not just measuring the cognitive domain, but it must be capable of measuring both affective and psychomotor domains. Problem-oriented learning should also lead to the right type of assessment. The component of the assessment in learning should be able to be associated with the values of characters expected to appear in the lesson.

These learning tools were developed with problem-based learning, so that the result also showed that the improvement of understanding the concept and the ability of students to think logically and critically. Learning tools which were contained with an authentic problems was a great opportunity in shaping and developing awareness of educators and students toward the understanding of meaning of speech that can be shown in the teaching-learning process.

In a particularly pragmatic language approach, the meaning of speech is determined by the context and context. But unlike the political world like the pansus, the language formula is not always true, because the language becomes a game. In this political world language is a great "mask" that is used to cover up what it wants to cover. Through language there will be explicit and implied interests and how individuals or groups use language or "show" and "hide" interests. This political language is defined as communication involving political messages and political actors, or in relation to government power, government, and policy.

Political language is the language as a political tool that is the words that come out of the mouth of people who like to promise without a commitment to keep his promise. In politics, language is just a sweetener lip. This can be seen 
during the campaign is certainly a lot of splatter words that are sweet on the lips only. However, aside from being a power tool the language can also come out in the form of words of wise advice preached by people who actually violate what he preaches. Therefore, critical thinking is needed to understand the meaning of speech from politicians.

The problems that leaded to the picture of the dilemma of the socio-political situation faced by society make it possible to be used in Pragmatics learning. The politicians' speeches in the socio-political life in Indonesia were full of veiled intentions, so it is suitable to analyze the meaning of the speech. To form a students' critical attitude requires learning that raises social dilemmas in social life [23]. In such social situations students were expected to be able to understand, sort out, and choose which actions would be taken to overcome the existing problems.

Problem-based learning is a learning model that uses realworld problems as a context for students to learn about critical thinking and problem-solving skills, and to acquire essential knowledge and concepts from subject matter, enrich and develop the knowledge, skills and attitudes [24]. The essential problem-based learning involves providing authentic and meaningful problem situations to students that can serve as a foundation for students to conduct analysis [25].

The point of learning is problem-solving. Defined that problem solving is part of a very important requirement because in the learning process, students may gain experience in using their knowledge and skills to be applied to solve the problems faced in everyday life [26]. "Real-world problems capture students' interest and are motivating", it can be interpreted that the daily problems can make students are interested and motivate students to learn.

Students who thought of a problem critically would not be satisfied with a clear or real solution, but it will suspend their judgment while searching for all relevant arguments, facts, and reasoning that can support good decision making. Argued that critical thinking uses the basic thought process to analyze opinions and produce which is more meaningful. Critical thinking and problem solving are closely related. Problem solving skills required critical thinking skills in exploring various alternative ways or solutions.

On the other hand, problem solving activity provided problematic situations that trigger the development of students' critical thinking potentials. It needs to be explored as a basis for developing both capabilities from the problem solving ability of learners can serve as an indicator of critical thinking ability.

\section{CONCLUSION}

Learning tools which were developed by lecturers should be based on predictions of future needs. In addition, the selection of models in the lecture also plays an important role in training students' skills in critical thinking. The results of this study indicated that learning tools needed to be designed and developed with problem-based learning. The focus of the development of Pragmatics learning tools oriented problem- based learning model included the development of syllabus, lesson plan, textbooks, media, and assessment.

This learning tool must also be synergized toward the problems related to the dilemma situation of social politic speech that was authentic and contextual. The learning model used learning tools which was oriented to socio-political problems that can improve students' understanding of the material concept of course being tauht and improve students' ability to think logically and critically in understanding speech.

The use of the language of politicians presented in this paper can be used as an alternative study materials in learning designed by educators to adapt socio-political events that enable learners to examine problems critically based on the material described in learning. This material is still limited to socio-political cases that can be associated with learning materials. Therefore, for other researchers is expected to conduct a more in-depth study related to the types of sociopolitical cases that allow use in directing students in thinking critically.

For the utilization of the learning tools, the learning tools was developed to meet the needs of the students and lecturers in Pragmatics course at the Department of Indonesian Langauge and Literature Education, Ganesha University of Education. Concerning its relevance to the lecture, this learning instruments needs to be reviewed when it is going to be used by the lecturers and the students outside our department.

\section{ACKNOWLEDGMENT}

I would like to say thank you very much to my teacher, Alm. Prof. Dr. Sumarsono, M.Ed., and Alm. Dr. Arifin, M.Pd. who always encouraged and gave me support to always work and want to deepen the pragmatic studies. Because of their support and encouragement, I always learn, find out, and understand Pragmatic concepts all over again. Of course any existing concepts are not simply acceptable; it takes the ability to think critically to understand it. Thank you my teacher, may you calm down there. Rest in peace.

\section{REFERENCES}

[1] Stephen C Levinson, Pragmatics, Cambridge:Cambridge University Press, 1986

[2] J. Cutting, Pragmatics and Discourse. London and New Yorks: Routledge, 2002

[3] Ekaning Krisnawati "Pragmatic competence in the spoken english classroom" Conaplin Journal Vol. 1, 2011

[4] T. Daniel Willingham, Critical thinking, why it is so hard to teach, American Federation of Teacher, 2007

[5] Arend Bridget, "Encouraging critical thinking in online threaded discussions", The Journal of Educators, vol. 6, pp 1-23, 2009

[6] S. Sungur, Tekkaya, "Effects of Problem-Based Learning and Traditional Instruction on Self-Regulated Learning" The Journal of Educational Research, Vol. 99, pp 307-317, 2006

[7] Jianping Shen, Sue Poppink, Yunhuo Cui, and Guorui Fan, "Lesson planning: a practice of professional responsibility and development" Educational Horizons Vol. 85, pp 248-259, 2007

[8] Slattery, J. M., Carlson, J. F, "Preparing an effective syllabus: Current best Practices", College Teaching, Vol. 53, pp 159-164, 2005. 
[9] Grunert J. "The course syllabus: A learning-centered approach, Bolton, MA: Anker, 1997.

[10] Habanek, D. V, "An examination of the integrity of the syllabus. College Teaching, Vol. 53, pp 62-64, 2005

[11] Smith, M. F. \& Razzouk, N. Y. "Improving classroom communication: the case of the course syllabus" Journal of Education for Business, Vol. 68, pp. 215-221, 1993

[12] Thiagarajan, S., Semmel, D. S., dan Semmel, M. L, Instructional developmnet for training teacher of exceptional children, Minnesota: Indiana University, 1974

[13] Marcis, J. G. \& Carr, D. R. " The course syllabus in the principles of economics: Anational survey" Atlantic Economic Journal, Vol. 32, pp 259,2004

[14] Matejka, K. \& Kurke, L. B. "Designing a great syllabus". College Teaching Vol. 42, pp115-117, 2004.

[15] Wong, Harry K, Rosemary T. Wong, "How to be an effective teacher the first days of school" Mountain view, CA: Harry T. Wong Publications, Inc.

[16] Farrell, T. S. C. "Lesson planning in methodology in language teaching: an anthology of current practice, Jack C. Richards (Editor), Willy A, New York: Cambridge University Press

[17] Volkan Cicek, "Effective use of lesson plans to enhance education", International Journal of Economy, Management and Social Sciences, Vol. 2, pp 334-341, 2013

[18] Sharon Calhoon, Becker, Angela "How students use the course syllabus" International Journal for the Scholarship of Teaching and Learning, Vol. 2, pp 1-12, 2008

[19] Protz, Babette Marisa. "Character education in print: content analysis of character education in introduction to education textbooks", Dissertation, The Faculty Of The University of North Carolina at Charlotte, 2013

[20] Marzuki, "Integration character value in learning' Jurnal Pendidikan Karakter Vol. 1, pp. 13, 2012

[21] Tyra, "Bringing books to life: teaching character education through children's literature" Journal Rising Tide, Vol. 5, pp 1-10, 2012

[22] Gijselaers. W.H, Conecting Based Practise with Educational Theory, New Direction for Theacing and Learning, Josey-Bass Publisher Nomor 68, 1996

[23] J.E. Maurice, S.J. Parker, Megan Kash, "The future of character education and social-emotional learning: the need for whole scholl and community-linked approaches" Journal of Research in Character Education Vol 2, pp 248-266, 2007

[24] S. Handayani, Sapir, "Effectiveness of problem-based learning model and cooperative learning jigsaw type to increase learning activity, learning outcomes and student learning response, JPE, Vol. 2, pp. 3852,2009

[25] Furgan Rahmadi, "Development of problem-based learning tools problem-oriented reasoning and mathematical communication pythagoras, Jurnal Pendidikan Matematika Vol 10, pp 137-145, Desember 2015

[26] Nitko, A.J., Brookhart, S.M, Educational assessment of students, Columbus: Merill, 2011 